\title{
Erratum: altered citation ID and delayed journal launch
}

\author{
Springer
}

\section{Erratum}

Due to a technical issue in production, two articles were assigned to the same URL after publication. This has caused an alteration to the citation ID of one article and has delayed the launch date of Textiles and Clothing Sustainability.

The citation ID of Ethical foundations in sustainable fashion (Niinimäki 2015) will be changed from 1 to 3 . This article will now be available at the following URL: http:// www.textclothsustain.com/content/1/1/3.

In addition, the following articles have a publication date prior to the launch date of the journal:

Thermoset composites reinforced with recycled cotton textile residues (Zonatti et al. 2015).

Sustainable apparel? Is the innovation in the business model? - The case of IOU Project (Gardetti and Muthu 2015).

Ethical foundations in sustainable fashion (Niinimäki 2015).

The publisher apologises for the delay to the launch of Textiles and Clothing Sustainability and for any inconvenience caused.

Received: 11 May 2015 Accepted: 11 May 2015

Published online: 17 June 2015

\section{References}

Gardetti, MA, \& Muthu, SS (2015). Sustainable apparel? Is the innovation in the business model? - The case of IOU Project. Textiles Clothing Sustain, 1, 2.

Niinimäki, K (2015). Ethical foundations in sustainable fashion. Textiles Clothing Sustain, 1, 3 .

Zonatti, W, Guimarães, BMG, Duleba, W, \& Baruque-Ramos, J (2015). Thermoset composites reinforced with recycled cotton textile residues. Textiles Clothing Sustain, 1,1 .

* Correspondence: editorial@textclothsustain.com

Springer-Verlag, GmbH, Tiergartenstr. 17, Heidelberg 69121, Germany

Submit your manuscript to a SpringerOpen ${ }^{\circ}$ journal and benefit from:

- Convenient online submission

- Rigorous peer review

- Immediate publication on acceptance

Open access: articles freely available online

- High visibility within the field

- Retaining the copyright to your article

Submit your next manuscript at $\gg$ springeropen.com 